\title{
スプリンクラー作動時の木製内 装材を用いた壁の燃焼実験
}

\section{BURNING EXPERIMENTS ON WALLS USING WOODEN INTERIOR FINISH WITH SPRINKLER ACTIVATING}

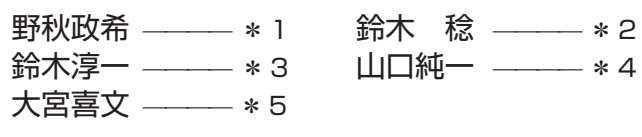

キーワード :

発熱速度, スプリンクラー設備, 炭化深さ, 木製内装材

Keywords:

Heat release rate, Sprinkler system, Char depth, Wooden interior finish

$\begin{array}{ll}\text { Masaki NOAKI_— } & * 1 \\ \text { Jun-ichi SUZUKI_—— } & * 3 \\ \text { Yoshifumi OHMIYA_— } & * 5\end{array}$

\section{Minoru SUZUKI - $* 2$}

Jun-ichi YAMAGUCHI $-* 4$

Several experiments were carried out to grasp burning behavior of wall using wooden interior material with sprinkler activating in unenclosed space. As for specimens, Japanese cedar plywood (24 mm thick) and lumber core plywood (12 mm thick) were selected. The size of specimens was $1820 \mathrm{~mm}$ wide and $2730 \mathrm{~mm}$ high. Regarding the experimental conditions, the incident heat flux onto the specimens by heat source was about $30 \mathrm{~kW} / \mathrm{m}^{2}$ at the distance of $455 \mathrm{~mm}$ from the bottom of the specimens, and water supply rate was $80 \mathrm{~L} / \mathrm{min}$. As the result of the experiments, heat release rate reached about $300 \mathrm{~kW}$ which was one of heat source after sprinkler activated. Char depths of the sprinkled specimens were less than $3 \mathrm{~mm}$.

\section{1. 研究背景及び目的}

スプリンクラー設備（以降、SP と呼ぶ）は代表的な初期消火設 備として知られている。現行の建築基準法の仕様規定では、SP お よび排煙設備を設けることにより、内装制限の防火規定が緩和また は除外される。これは SP が内装の燃焼を抑制・消火する効果を期 待しているためと考えられる。しかし、現行の避難安全検証法や耐 火性能検証法では、可燃性内装材の燃焼性状は SP の有無によらず 同じものとして扱われている。これは、SP 作動時の可燃性内装材 の燃焼性状が定量的に把握されていないことが一因と考えられる。

過去には、大宮ら 1),2)が木製の鉛直壁に対し散水と加熱を同時に 行う実験を実施し、散水の有無による炭化深さの違いを検討してい る。また、岡島 3)や土橋ら 4) は木製壁を着火させないために必要な 散水量について検討を行っている。しかし、SP 作動時の可燃性内 装材の燃焼性状の把握を目的として実施された研究は見られない。

そこで本研究では、SP 作動時における木製内装材を用いた壁の 発熱速度などの燃焼性状に関する定量的知見の収集を目的とし、自 由空間において木製内装材を模擬した合板の壁を初期火災程度の火 源で加熱する実験を実施した。

\section{2. 実験概要}

図 1 に実験概要図を示す。集煙フード下の自由空間において図 1 に示すように、鉛直に設置した合板（試験体）を下方から加熱し燃 焼させた。主要な実験変数は、試験体への散水の有無、合板の種類 である。なお、自由空間で実験を行ったのは、燃焼によって形成さ れる煙層等の影響を受けないようにするためである。

\section{1 実験装置}

実験は東京理科大学火災科学研究センター実験棟の集煙フードの 下で実施した。本実験では、汎用的に使用されている SPヘッド (千 住スプリンクラー製、閉鎖型湿式スプリンクラーヘッド、高感度型、 型番：VQR、流量係数 $\mathrm{K}=80[\mathrm{~L} / \mathrm{min} / 0.1 \mathrm{MPa}])$ を用い、 $\mathrm{SP}$ ヘッド と試験体表面からの水平距離を $1.84 \mathrm{~m}$ 注 1)、設置高さを床から 3.45 m（試験体の上端と同じ高さ）とした。また、送水用のポンプと SP ヘッドの間にデジタル流量計（堀場エステック社製、型番： LD20-PATAAA-RC、流量範囲 : $3.0 \sim 60 \mathrm{~L} / \mathrm{min}$ 、RS 精度 : $\pm 2 \%$ ) を 2 台並列に設置し、配管に設置されたバルブを開閉することで指 示值が所定の值になるよう $\mathrm{SP}$ ヘッドに供給する水量を調整した。

火源は試験体の下に設置したガスバーナー (燃料: 都市ガス $13 \mathrm{~A}$ ) とし、試験開始と同時にガス供給量を調整した。なお、ガス供給量 が安定するまでは試験体下端に長さ $0.9 \mathrm{~m}$ 幅 $2.0 \mathrm{~m}$ の保護板を設け、 火炎が試験体に当たらないよう配慮した注 2)。

\section{2 試験体概要}

本実験では木製材料として一般的であり、密度と厚みの異なる 2 種類の合板を使用した。一方は密度が $450 \sim 470 \mathrm{~kg} / \mathrm{m}^{3}$ 、厚み $24 \mathrm{~mm}$ の構造用合板（樹種：スギ、以降、合板 $\mathrm{A}$ と呼ぶ）、他方は密度が $375 \mathrm{~kg} / \mathrm{m}^{3}$ 、厚み $12 \mathrm{~mm}$ のランバーコア合板（樹種 : シナ、以降、 合板 B と呼ぶ）である。また、試験体は $0.91 \mathrm{~m} \times 1.82 \mathrm{~m}$ の合板 A、 合板 $\mathrm{B}$ の板を 3 枚横張りに張り上げ、 $2.73 \mathrm{~m} \times 1.82 \mathrm{~m}$ の鋼製のフレ ームにボルトで留め付けた。表 1 に試験体の仕様等を示す。

なお、本実験に先駆けて、合板 $\mathrm{A}$ および合板 $\mathrm{B}$ の基礎的な燃焼性 状をコーンカロリーメータ試験装置を用いて調查した。

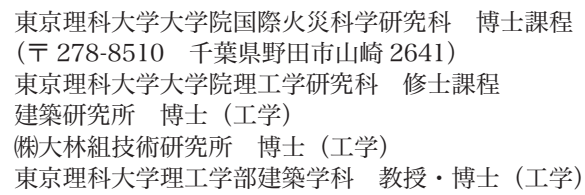

'l Doctoral Course, Grad. Sch. of Global Fire Sci. and Tech., Tokyo Univ. of Science

Master's Course, Grad. Sch. of Sci. and Eng., Tokyo Univ. of Science Building Research Institute, Dr. Eng.

Obayashi Corporation Technical Research Institute, Dr. Eng.

Prof., Faculty of Engineering, Tokyo Univ. of Science, Dr. Eng. 


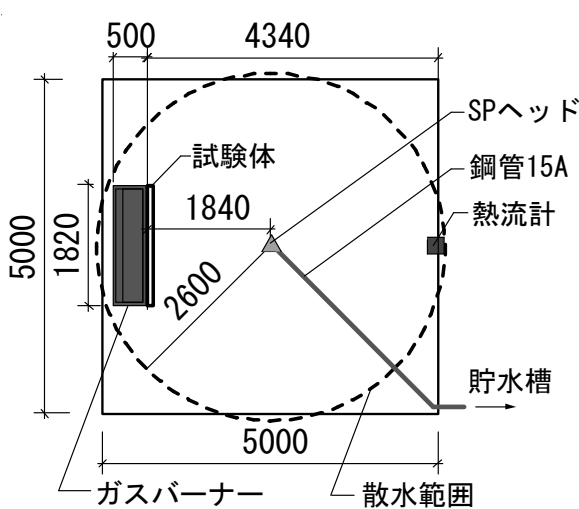

(a) 平面図

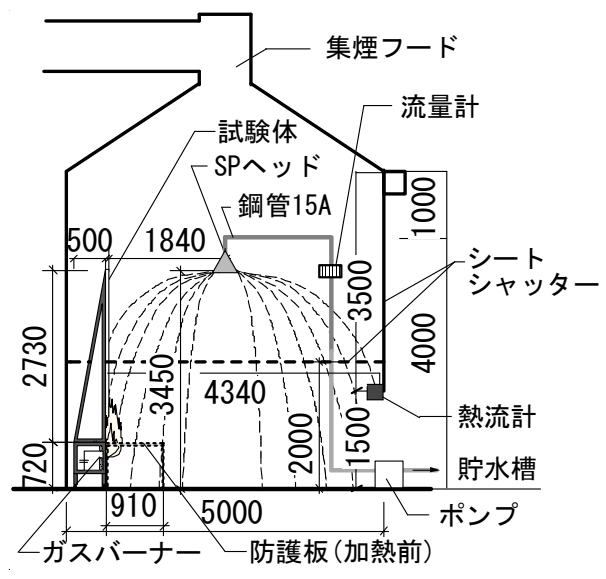

(b) 断面図

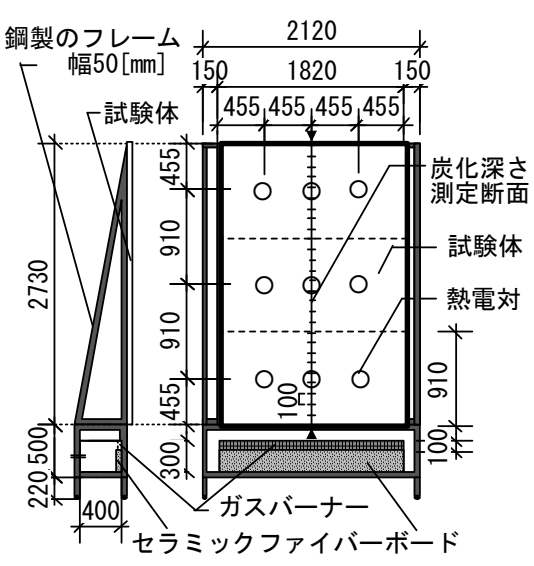

(c) 試験体配置図

図 1 実験概要図（単位： $\mathrm{mm}$ )

コーンカロリーメータ試験では、加熱強度をパラメータとして 50 $30,15 \mathrm{~kW} / \mathrm{m}^{2}$ の 3 条件とし、着火時間、発熱速度、重量減少を測定 した。表 2 に実験条件および実験結果の概要、図 2 に各試験体の発 熱速度の経時変化を加熱強度別に整理した結果を示す。図 2 よりい ずれの合板においても加熱強度が高いほど、任意の時刻における発

表 1 試験体の仕様

\begin{tabular}{|c|c|c|c|c|c|c|}
\hline 可燃物 & $\begin{array}{c}\text { 寸法 [mm] } \\
\text { (幅×高さ×厚み) }\end{array}$ & $\begin{array}{l}\text { 重量 } \\
{[\mathrm{kg}]}\end{array}$ & $\begin{array}{c}\text { 密度 } \\
{\left[\mathrm{kg} / \mathrm{m}^{3}\right]}\end{array}$ & $\begin{array}{l}\text { 含水率 } \\
{[\%]^{*}}\end{array}$ & $\begin{array}{c}\text { 加熱時間 } \\
{[\mathrm{min}]}\end{array}$ & $\begin{array}{c}\text { 散水開始時間 } \\
{[\mathrm{s}]}\end{array}$ \\
\hline \multirow{2}{*}{ 合板A } & \multirow{2}{*}{$1820 \times 2730 \times 24$} & 54.9 & 460.4 & \multirow{2}{*}{10.1} & 36.0 & - \\
\hline & & 54.0 & 452.8 & & 20.0 & 120 \\
\hline \multirow{2}{*}{ 合板B } & \multirow{2}{*}{$1820 \times 2730 \times 12$} & 22.4 & 375.7 & \multirow{2}{*}{10.0} & 13.5 & - \\
\hline & & 22.4 & 375.7 & & 10.0 & 120 \\
\hline
\end{tabular}

※ 試験体と同じロットの $100 \mathrm{~mm}$ 角の各合板を $105^{\circ} \mathrm{Cl}$ 約 24 時間保持し、全乾法にて試験体 の含水率を推定した。

表 2 コーンカロリーメータ試験の実験条件および実験結果の概要

\begin{tabular}{|c|c|c|c|c|c|c|c|c|}
\hline \multirow[b]{2}{*}{ 試験体 } & \multicolumn{3}{|c|}{ 実験条件 } & \multicolumn{5}{|c|}{ 実験結果 } \\
\hline & $\begin{array}{c}\text { 加熱強度 } \\
{\left[\mathrm{kW} / \mathrm{m}^{2}\right]}\end{array}$ & $\begin{array}{c}\text { 密度 } \\
{\left[\mathrm{kg} / \mathrm{m}^{3}\right]}\end{array}$ & $\begin{array}{l}\text { 含水率 } \\
{[\%]^{*}}\end{array}$ & \begin{tabular}{|c} 
着火時間 \\
{$[\mathrm{s}]$}
\end{tabular} & \begin{tabular}{|c} 
最大 \\
発熱速度 \\
{$\left[\mathrm{kW} / \mathrm{m}^{2}\right]$}
\end{tabular} & $\begin{array}{c}\text { 燃焼熱 } \\
{[\mathrm{JJ} / \mathrm{g}]}\end{array}$ & \begin{tabular}{|l} 
総発熱量量 \\
{$\left[\mathrm{MJ} / \mathrm{m}^{2}\right]$}
\end{tabular} & $\begin{array}{c}\text { 総重量 } \\
\text { 減少 } \\
{[\mathrm{g}]}\end{array}$ \\
\hline \multirow{3}{*}{ 合板A } & 50 & 460 & \multirow{3}{*}{10.1} & 28.2 & 322.4 & 12.6 & 121.9 & 85.2 \\
\hline & 30 & 470 & & 62.0 & 275.1 & 11.7 & 113.5 & 88.1 \\
\hline & 15 & 450 & & $\bar{x}$ & $x$ & $x$ & $x$ & 7.4 \\
\hline \multirow{3}{*}{ 合板B } & 50 & 300 & \multirow{3}{*}{10.0} & 11.7 & 287.8 & 13.5 & 47.8 & 31.4 \\
\hline & 30 & 320 & & 36.7 & 228.7 & 11.7 & 41.3 & 31.8 \\
\hline & 15 & 330 & & $x$ & $x$ & $x$ & $x$ & 7.3 \\
\hline
\end{tabular}

メは着火していないため値を記載していない。

※ 試験体と同じロットの $100 \mathrm{~mm}$ 角の各合板を $105^{\circ} \mathrm{Cl}$ 約 24 時間放置し、全乾法にて試験体 の含水率を推定した。

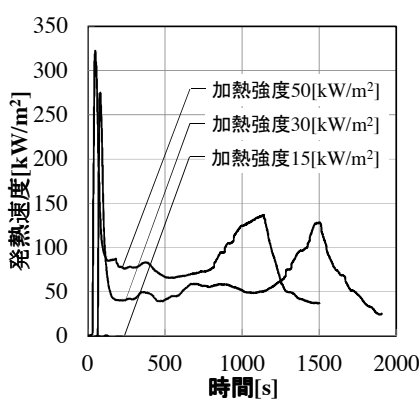

(i)合板 A

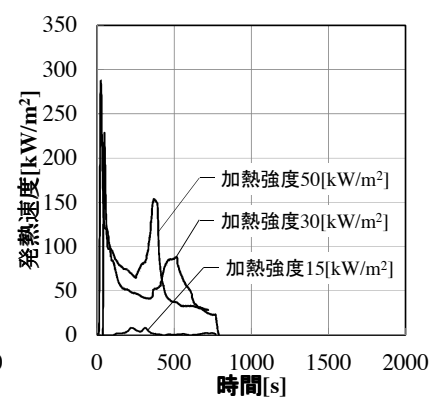

(ii)合板 B
図 2 コーンカロリーメータ試験における試験体の発熱速度
熱速度が高くなる傾向を示している。また、加熱強度 $30 \mathrm{~kW} / \mathrm{m}^{2} 、 50$ $\mathrm{kW} / \mathrm{m}^{2}$ いずれにおいても、合板 $\mathrm{A}$ に比べ合板 B の着火時間の方が短 かった。さらに、加熱強度 $15 \mathrm{~kW} / \mathrm{m}^{2}$ ではいずれの合板も着火しなか った注3)。

\section{3 実験条件}

散水条件（散水量および散水開始時間）と加熱条件（火源の仕様 および加熱時間）を以下に示す。

\section{3.1 散水量および散水開始時間}

散水量は消防法で定められている閉鎖型湿式スプリンクラー設備 の標準型および高感度型スプリンクラーヘッドの必要水量の最小值 である $80 \mathrm{~L} / \mathrm{min}$ とした。また、散水開始時間は散水無しの発熱速 度が最大值を迎えた時間とした。

\subsection{2 火源の仕様および加熱時間}

試験体幅方向を均一に加熱するため、火源（ガスバーナー）の幅 を $1.8 \mathrm{~m}$ とした。また、ガス配管に水が入りガスの供給量が不安定 にならないよう、火炎の噴出口を水平方向に向け噴出口の高さを $0.1 \mathrm{~m}$ とした。さらに、火源の発熱速度は模型箱試験（内装材の燃 焼性状を確認する試験装置）の火源を参考とし、火源の連続火炎高 さが模型箱試験の火源 (平面寸法 $0.17 \mathrm{~m} \times 0.17 \mathrm{~m}$ 、発熱速度 $40 \mathrm{~kW}$ ) の火炎高さと概称等しくなるよう $300 \mathrm{~kW}$ とした。なお、ガスバー ナー単位幅あたりの発熱速度は約 $160 \mathrm{~kW} / \mathrm{m}$ である。

加熱時間は、散水無しの場合、試験体の一部が燃え抜けるまでと し、散水有りの場合、試験体の温度や発熱速度等に時間変化が見ら れなくなるまでとした。

\section{4 測定項目}

本実験の測定項目および測定方法は以下の通りである。

(1) 試験体に供給される散水量および散水範囲: 試験体の代わりに けい酸カルシウム板（比重 0.8 、板厚 $10 \mathrm{~mm}$ ）の表面にアルミ箔を 張った壁を用いて、図 3 に示寸ように面積 $0.1 \mathrm{~m}^{2}$ の正方形の散水マ スを壁の下端に 6 個設置し、3 分間に散水マス内に溜まった水量を 2 回測定した。また、散水中及び散水後に撮影した写真から散水範 囲を確認した。

(2) 火源から試験体一入射する熱流束: 試験体の代わりに無機材（け い酸カルシウム板（比重 $0.8 、 10 \mathrm{~mm}$ 厚）にセラミックファイバー ブランケット $(12.5 \mathrm{~mm}$ 厚) を上張りしたもの) の壁を用いて、壁 


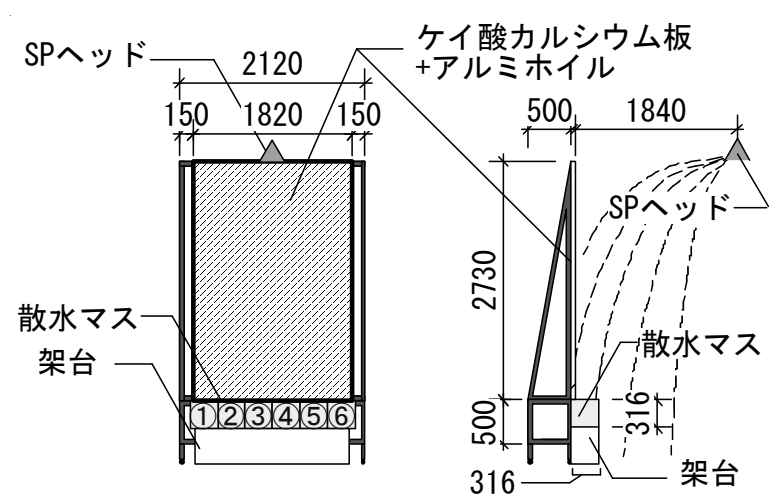

図 3 試験体に供給される散水量の測定概要（単位：mm)

の下端から高さ 455、1365、2275 mm の位置に Gardon 型熱流計 (Vatell 社製、全熱流タイプ、水冷式、熱流束範囲 $0 \sim 200 \mathrm{~kW} / \mathrm{m}^{2}$ 、 較正精度 : $\pm 3 \%$ 、再現性 : $\pm 1 \%$ ）を設置し、火源から試験体一 入射する熱流束を測定した。

(3) 発熱速度 : 集煙フードで収集した燃焼生成ガスのガス濃度を測 定し、酸素消費法により発熱速度を算出した注 4 )。

(4) 炭化深さ：試験終了後、試験体の炭化部をワイヤーブラシで除 去後、測定した未炭化部の厚さを試験体の初期厚さから減じて炭化 深さを算出した。なお、炭化深さの測定断面は図 1(c)に示すとおり 試験体の中央とし、高さ方向に $100 \mathrm{~mm}$ 間隔で測定した。

(5) 試験体裏面温度 : 図 1(c)に示した位置の計 9 カ所に K 型熱電対 $\varphi 0.32 \mathrm{~mm}$ を設置し、試験体の裏面温度を測定した。

(6) 対向面の入射熱流束 : 試験体表面から距離 $4.34 \mathrm{~m}$ 、床からの高 さ $1.5 \mathrm{~m}$ の位置に Gardon 型熱流計（CAPTEC 社製、放射熱タイプ、 水冷式、熱流束範囲 $0 \sim 500 \mathrm{~kW} / \mathrm{m}^{2}$ 、直線性 : $\pm 2 \%$ ）を正対させ、 入射する熱流束を測定した。

(7) 燃焼面積および燃焼中の様子 : 実験中及び実験終了後の様子を カメラ、ビデオ、目視で確認した。

\section{3. 実験結果}

\section{1 試験体に供給される散水量および散水範囲}

表 3 は試験体表面に供給される散水量を測定した結果である注 5)。 表 3 より試験体向かって左側ほど散水量が幾分小さい傾向にある。 これは、SP ヘッドが放出する散水量に指向性があるためと考えら れる。なお、単位幅当たりに供給される平均散水量（散水量 $\div$ 散水 時間 $\div$ 試験体幅）は $49.2 \mathrm{~g} / \mathrm{s} / \mathrm{m}$ であった。また、写真 1 に測定終了 後の試験体表面の様子を示す。なお、写真 1 の白い点線は試験体が 散水されていた範囲を表しており、その面積（散水面積）は $4.54 \mathrm{~m}^{2}$ であった。また、試験体の散水範囲の単位面積当たりの散水量（散 水量 $\div$ 散水時間 $\div$ 散水面積）を計算すると $20.56 \mathrm{~g} / \mathrm{s} / \mathrm{m}^{2}$ となった。

表 3 試験体に供給される散水量

\begin{tabular}{|c|c|c|c|c|c|c|}
\hline \multirow{2}{*}{ 散水マス } & \multicolumn{3}{|c|}{ 試験体に供給される散水量 $[\mathrm{g} / \mathrm{s}]$} \\
\cline { 2 - 7 } & 1 & 2) & (3) & 4 & (5) & 6 \\
\hline \hline 1回目 & 8.3 & 13.9 & 15.6 & 15.6 & 18.3 & 20.0 \\
\hline 2回目 & 8.3 & 14.5 & 16.1 & 15.6 & 21.7 & 18.9 \\
\hline 平均値 & \multicolumn{6}{|c|}{15.6} \\
\hline \hline $\begin{array}{l}\text { 幅当たりの } \\
\text { 平均散水量 }\end{array}$ & \multicolumn{7}{|c|}{$49.2[\mathrm{~g} / \mathrm{s} / \mathrm{m}]$} \\
\hline
\end{tabular}

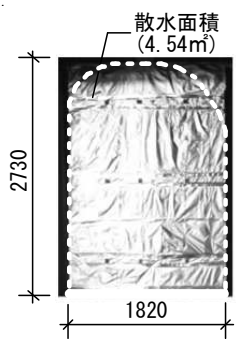

写真 1 散水範囲

\section{2 火源から試験体へ入射する熱流束}

図 4 に散水無しにおける試験体の入射熱流束の経時変化を高さご とに整理した結果を示す。図 4 より入射熱流束は加熱開始直後から 高さごとに概衩一定の值で推移した。このとき、試験体中央下端か ら高さ $\mathrm{H}=455[\mathrm{~mm}]$ の位置で約 $30\left[\mathrm{~kW} / \mathrm{m}^{2}\right] 、 \mathrm{H}=1365[\mathrm{~mm}]$ で約 $15\left[\mathrm{~kW} / \mathrm{m}^{2}\right] 、 \mathrm{H}=2275[\mathrm{~mm}]$ で約 $7\left[\mathrm{~kW} / \mathrm{m}^{2}\right]$ であることが確認できる。

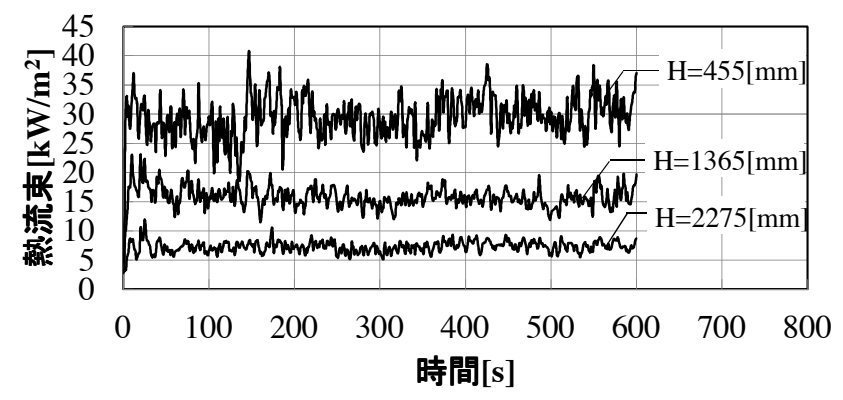

図 4 試験体の入射熱流束の高さ分布（散水無し）

\section{3 観察記録}

(1) 合板 A

写真 2(i)は散水無しの合板 A の燃焼の様子である。加熱開始後、 ガスバーナーからの火炎が試験体の下端から $1 \mathrm{~m}$ 程度まで到達した。 加熱開始後 1 分程度で試験体表面が炭化する様子が確認できた。試 験体が着火すると火炎高さは増加し、一旦火炎高さが試験体上端ま で到達した後、時間とともに減衰した。これは、合板の燃焼に伴っ て生じた炭化層が断熱層となり、合板の未燃焼部分に入射する正味 の熱流束が低減され、燃焼が緩慢になったためと考えられる。加熱 開始後 10 分経過すると、連続火炎高さは試験体下端から $1 \mathrm{~m}$ 程度 で安定し、加熱開始 36 分程度で試験体が燃え抜けた。

写真 2(ii) は散水有りの合板 A の燃焼の様子である。散水有りの場 合、散水開始直後に試験体の火炎は消え、試験体表面は常に濡れた 状態であり、ドライパッチは見受けられなかった。

(2) 合板 B

写真 3(i) は散水無しの合板 B の燃焼の様子である。試験開始後、 ガスバーナーからの火炎が試験体下端から $1 \mathrm{~m}$ 程度まで到達し、1 分程度で試験体表面が炭化する様子が確認できた。その後火炎が上 方に伝播し試験体下端から約 $3 \mathrm{~m}$ まで到達した後、次第に火炎高さ が減衰し、連続火炎高さが $1 \mathrm{~m}$ 程度で安定した。また、試験開始 13 分程度で試験体が燃え抜け、試験を終了した。

写真 3(ii)は散水有りの合板 B の燃焼の様子である。散水有りの場 合、試験体表面や火炎の様子は合板 A と同様であった。

\section{4 発熱速度}

図 5 に各試験体の発熱速度の経時変化を示す。なお、図 5 に示 した発熱速度はガスバーナーの発熱速度 $(300 \mathrm{~kW})$ も含んでいる。 図 5 より散水無しの場合、加熱開始 120 秒程度で発熱速度は、合板 $\mathrm{A}$ の場合 $750 \mathrm{~kW}$ 程度、合板 B の場合 $800 \mathrm{~kW}$ 程度でピークを迎え、 その後時間と共に減少する傾向を示した。また、いずれの試験体に おいても、散水開始直後から発熱速度が減少し、ガスバーナーの発 熱速度と概初同じ值まで低減されている。これは、散水により試験 体の燃焼が抑制され、ほとんど発熱していないためと考えられる。 


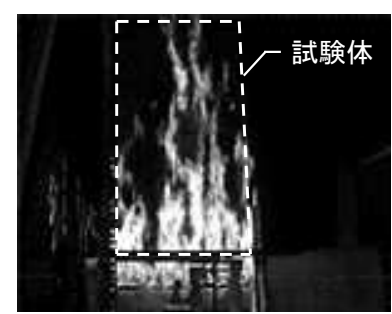

(a) 試験開始 $120[\mathrm{~s}]$ 後

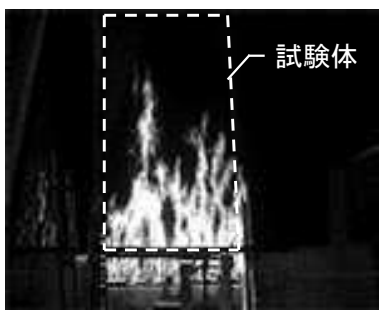

(b) 試験開始 $150[\mathrm{~s}]$ 後

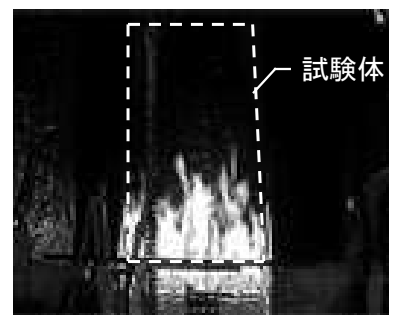

(c) 試験開始 $600[\mathrm{~s}]$ 後

(i )散水無し

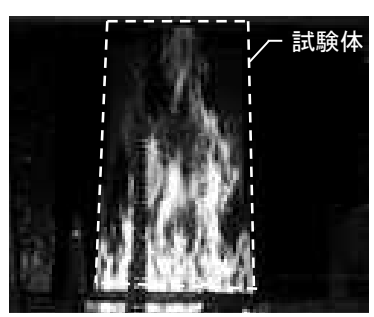
(散水開始 $0[\mathrm{~s}]$ 後)

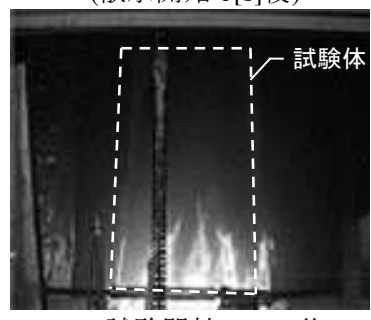

(b) 試験開始 $150[\mathrm{~s}]$ 後 (散水開始 $30[\mathrm{~s}]$ 後)

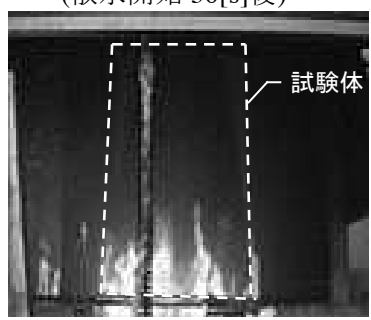

(c) 試験開始 $600[\mathrm{~s}]$ 後 (散水開始 480[s]後)

(ii) 散水有り (a) 試験開始 $120[\mathrm{~s}]$ 後

写真 2 合板 $\mathrm{A}$ の燃焼の様子

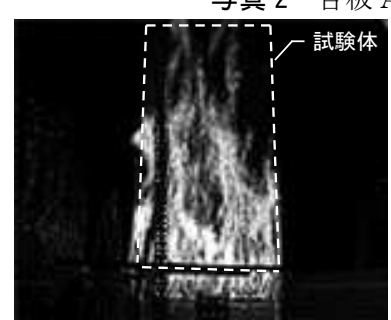

（a）試験開始 $120[\mathrm{~s}]$ 後

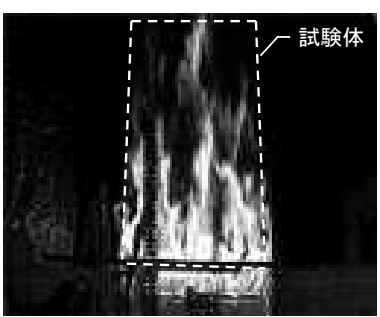

（b）試験開始 $150[\mathrm{~s}]$ 後

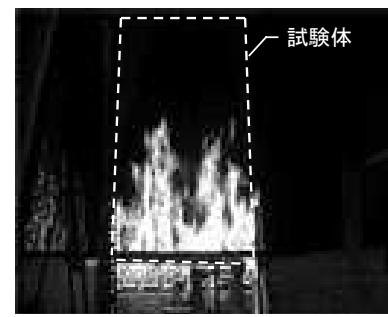

(c) 試験開始 $600[\mathrm{~s}]$ 後

(i ) 散水無し

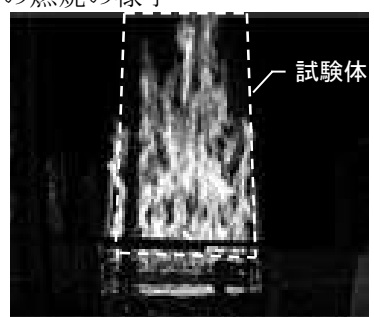

(a) 試験開始 $120[\mathrm{~s}]$ 後 (散水開始 $0[\mathrm{~s}]$ )

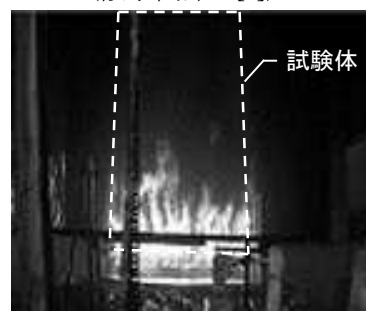

(b) 試験開始 $150[\mathrm{~s}]$ 後 (散水開始 $30[\mathrm{~s}]$ 後)

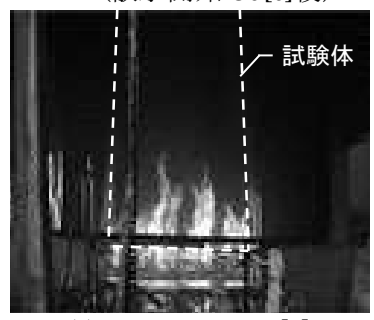

(c) 試験開始 $600[\mathrm{~s}]$ 後 (散水開始 480[s]後) (ii) 散水有り

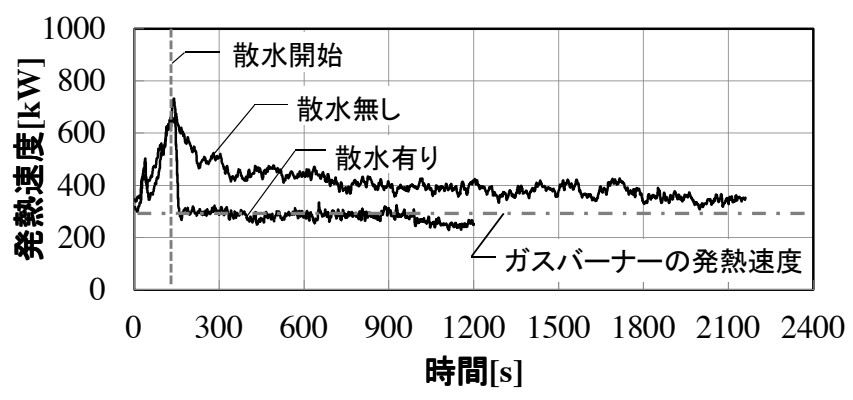

(i) 合板 $\mathrm{A}$

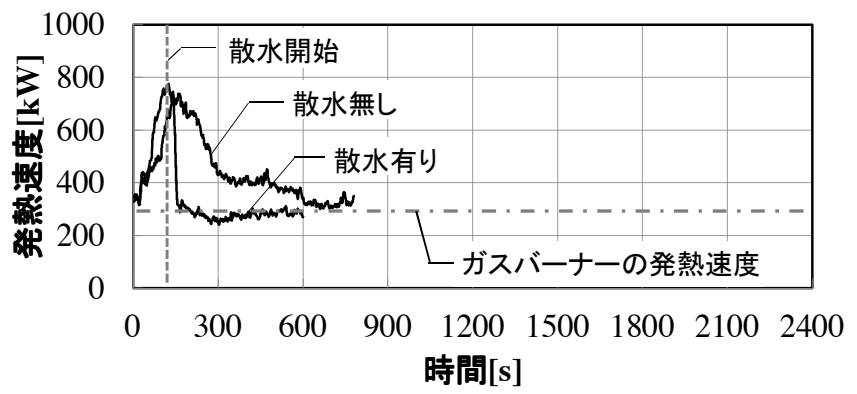

(ii) 合板 B

図 5 各試験体の発熱速度

\section{5 炭化面積}

写真 4 は試験終了後の各試験体の様子である。写真 4 よりいずれ の試験体も上に凸の放物線状に炭化していることが確認できる。ま た、表 4 に試験体表面が炭化した面積（以降、炭化面積と呼ぶ）を 示す。表 4 より、合板 $\mathrm{A}$ の炭化面積は散水無しで $3.48 \mathrm{~m}^{2}$ 、散水有 りで $3.74 \mathrm{~m}^{2}$ であり、合板 $\mathrm{B}$ の炭化面積は散水無しで $4.27 \mathrm{~m}^{2}$ 、散水 有りで $4.45 \mathrm{~m}^{2}$ であった。また、各試験体の最大発熱速度を炭化面 積で除し、試験体の単位面積当たりの発熱速度を計算した結果を表 4 に示す。表 4 より合板 A、合板 B の単位面積当たりの発熱速度は $100 \sim 120 \mathrm{~kW} / \mathrm{m}^{2}$ 程度となった。

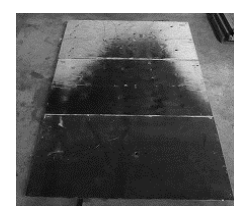

(i ) 散水有り

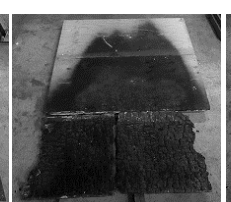

(ii )散水無 L

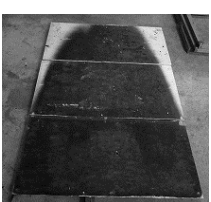

(i )散水有り

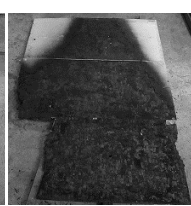

(ii 散水無し
(1)合板 A

(2)合板 B

写真 4 各試験体の試験後の様子

表 4 試験体表面が炭化した面積

\begin{tabular}{|l|c|c|c|c|}
\hline & \multicolumn{2}{|c|}{ 合板A } & \multicolumn{2}{c|}{ 合板B } \\
\cline { 2 - 5 } & 散水有り & 散水無し & 散水有り & 散水無し \\
\hline \hline 炭化面積 $\left[\mathrm{m}^{2}\right]$ & 3.48 & 3.74 & 4.45 & 4.27 \\
\hline 最大発熱速度 $[\mathrm{kW}]^{\text {※ }}$ & 432 & 375 & 476 & 445 \\
\hline $\begin{array}{l}\text { 単位面積当たりの } \\
\text { 最大発熱速度 }\left[\mathrm{kW} / \mathrm{m}^{2}\right]\end{array}$ & 124.1 & 100.3 & 106.9 & 104.2 \\
\hline
\end{tabular}

※ 酸素消費法で測定した最大発熱速度からガスバーナーの発熱速度 $(300 \mathrm{~kW})$ を減じて いる。

写真 3 合板 B の燃焼の様子 


\section{6 炭化深さ}

図 6 に試験体中央の炭化深さの高さ分布を示す。図 6 より散水無 しの場合、合板 A で試験体下端から $0.9 \mathrm{~m}$ 、合板 B で試験体下端か ら $1.2 \mathrm{~m}$ まで炭化深さに変化は見られないが、これ以上の高さでは 上方に向かうほど炭化深さは小さくなり、高さ $1.5 \mathrm{~m}$ 以上では $3 \mathrm{~mm}$ 以下となっている。これは、火炎高さの時間変化から確認したとお り、実験後半では連続火炎高さが $1 \mathrm{~m}$ 程度で安定しており、試験体 はこの高さまで継続的に加熱されたためと考えられる。なお、散水 無しでは試験体が然え抜けるまで加熱を行っているが、合板 B の場 合、ガスバーナーからの火炎により試験体両脇の小口が加熱された ことにより両端部が先行して燃え抜けたため、試験体中央の炭化深 さは合板厚みまで到達していない。

また、散水無しの場合について、試験体下端から炭化深さが変化 しない高さまで試験体が継続的に燃焼していたと考え、式(1)を用い て発熱速度が概衫安定している時間における単位面積当たりの発熱 速度を算出した。その結果、合板 $\mathrm{A}$ および合板 $\mathrm{B}$ の単位面積当たり の発熱速度はそれぞれ $58 \mathrm{~kW} / \mathrm{m}^{2} 、 48 \mathrm{~kW} / \mathrm{m}^{2}$ となった。

$$
Q^{\prime \prime}=\frac{Q_{\text {ave }}}{H_{\text {char }} \cdot W}
$$

ここで、 $Q$ ”は単位面積当たりの発熱速度 $\mathrm{kW} / \mathrm{m}^{2} 、 Q_{a v e}$ は発熱速度が 概放安定している時間の平均発熱速度 $\mathrm{kW} 、 H_{\text {char }}$ は試験体下端から 炭化深さに変化が見られない高さ（合板 A では $0.9 \mathrm{~m} 、$ 合板 B では $1.2 \mathrm{~m}) 、 W$ は試験体幅 $(=1.82 \mathrm{~m})$ である。このとき、Q $Q_{a v e}$ は酸素消 費法で測定した発熱速度(図 5) からガスバーナーの発熱速度 $300 \mathrm{~kW}$ を減じた值とし、合板 $\mathrm{A}$ の場合 750〜 $1200 \mathrm{~s}$ の平均值として $95 \mathrm{~kW}$ 、 合板 B の場合 $360 \sim 420 \mathrm{~s}$ の平均値として $104 \mathrm{~kW}$ と与えた。

また、散水有りの場合、合板 A、合板 B ともにいずれの高さにお いても炭化深さは $3 \mathrm{~mm}$ 以下となっており、散水による炭化抑制効 果が確認できる。

\section{7 試験体裏面温度}

図 7 に試験体の裏面温度の経時変化を測定高さごとに整理した結 果を示す。なお、各測定高さにおける試験体の裏面温度には顕著な バラつきが見られなかったため、図 7 には各高さ 3 点の測定值の平 均值を示している。図 7 より合板 A、合板 B ともに加熱開始後、裏 面温度は時間の経過と共に概称増加し続けている。しかし、散水有 りの場合、合板 $\mathrm{A}$ では散水開始後、裏面温度が $15 \sim 30{ }^{\circ} \mathrm{C}$ 程度で推 移している。また、合板 $\mathrm{B}$ の場合、散水開始までに約 $60{ }^{\circ} \mathrm{C}$ まで温 度が上昇しているが散水開始後、裏面温度が $20 \sim 40{ }^{\circ} \mathrm{C}$ まで低下して いる。これは、散水により試験体表面に入射する熱流束が減少し、 試験体内部一の熱の伝搬が抑制されているためと考えられる。

\section{8 対向面の入射熱流束}

図 8 は試験体表面から $4.34 \mathrm{~m}$ 離れた対向面の入射熱流束の経時 変化である。図 8 より散水無しの場合、対向面の入射熱流束は、合 板 A で最大約 $1.2 \mathrm{~kW} / \mathrm{m}^{2}$ 、合板 B で最大約 $1.6 \mathrm{~kW} / \mathrm{m}^{2}$ であるのに 対し、散水有りの場合、散水開始後約 $0.1 \mathrm{~kW} / \mathrm{m}^{2}$ まで低減されてい ることが確認できる。これは、散水により試験体表面の温度が低下 したことやスプリンクラーから放出した水滴群が放射熱を吸収した ことなどが原因と考えられる。

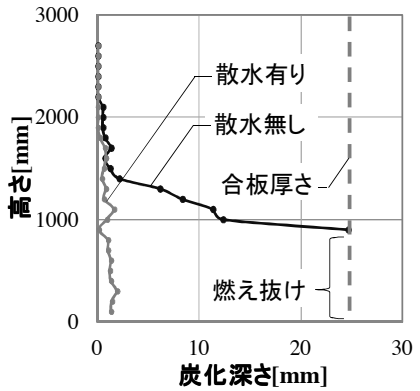

(i) 合板 $\mathrm{A}$

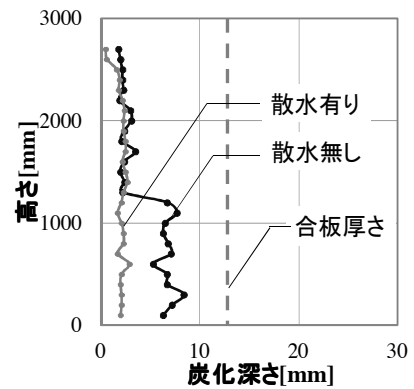

(ii) 合板 B
図 6 各試験体の炭化深さ

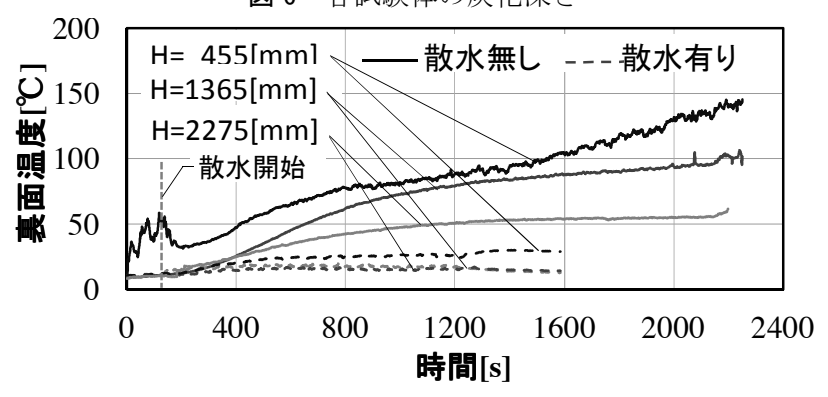

(i) 合板 $\mathrm{A}$

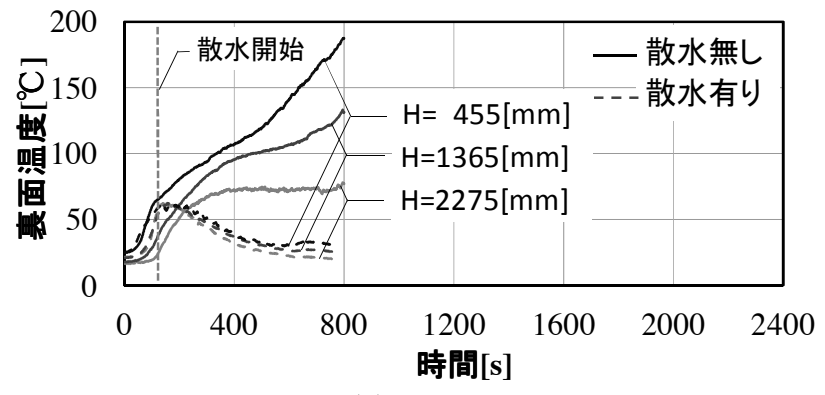

(ii) 合板 B

図 7 各試験体の裏面温度

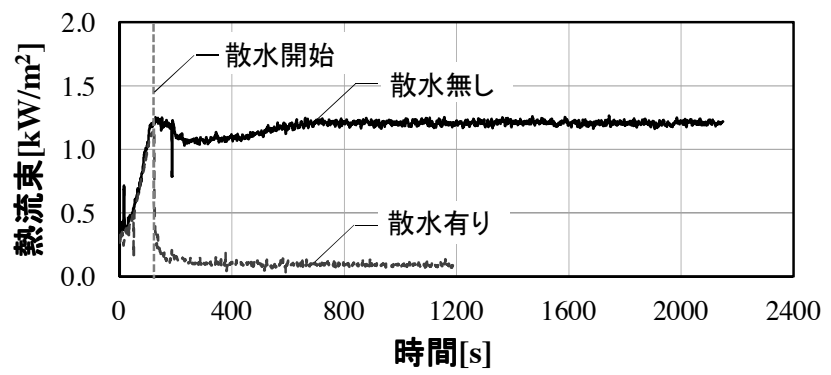

(i) 合板 $\mathrm{A}$

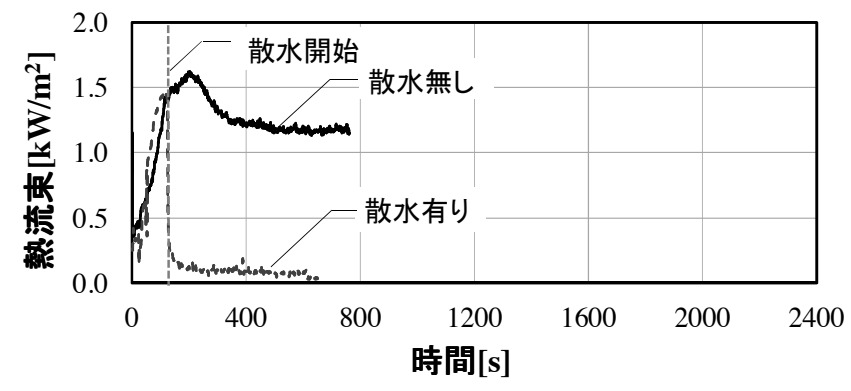

(ii) 合板 B

図 8 対向面の入射熱流束 


\section{4. 炭化速度に関する考察}

本節では、本実験の結果および既往の実験結果 2)3)を用いて、散水 の有無による炭化速度の違いを確認する。ここで、本論文では炭化 深さを加熱時間で除した值を炭化速度とした。このとき、炭化深さ は図 6 において、合板 $\mathrm{A}$ では $0.9 \mathrm{~m}$ 、合板 B では $1.2 \mathrm{~m}$ 以下の部分 の平均值を採用した。各試験体の炭化深さの平均值と加熱時間を整 理した結果を表 5 に示す。

図 9 は本実験と文献 2 )および文献 3)における試験体一の入射熱流 束と炭化速度を整理した結果である。このとき、図 4 より試験体下 端から $455 \mathrm{~mm}$ における入射熱流束の時間平均值が $30 \mathrm{~kW} / \mathrm{m}^{2}$ であ ることから、本実験結果の入射熱流束を $30 \mathrm{~kW} / \mathrm{m}^{2}$ としてプロット している。なお、図 9 には Butler5)により提案された式も示してい る。図 9 より散水無しの場合、一部の条件を除き、炭化速度はButler の式の計算值と概䄈一致した。ただし、文献 3)はこの計算值を幾分 下回った。これは Butler の式は密度の小さい木材の炭化速度の予測 を対象としているため、文献 3)で使用した樹種（カラマツなど）の ように密度が大きい木材には適用できない可能性を示唆している。

一方、散水有りの場合、いずれの条件においても炭化速度は 0.2 $\mathrm{mm} / \mathrm{min}$ 以下となっており、散水により炭化が抑制されており、本 実験の結果と文献 2)および文献 3)の結果が概ね等しいことが確認 できる。ただし、SP 実験（合板 B）の炭化速度のみ、他の試験体 に比心゙幾分炭化速度が大きいのは、散水開始までに炭化した厚みに 対し加熱時間が短かったことが原因と考えられる。

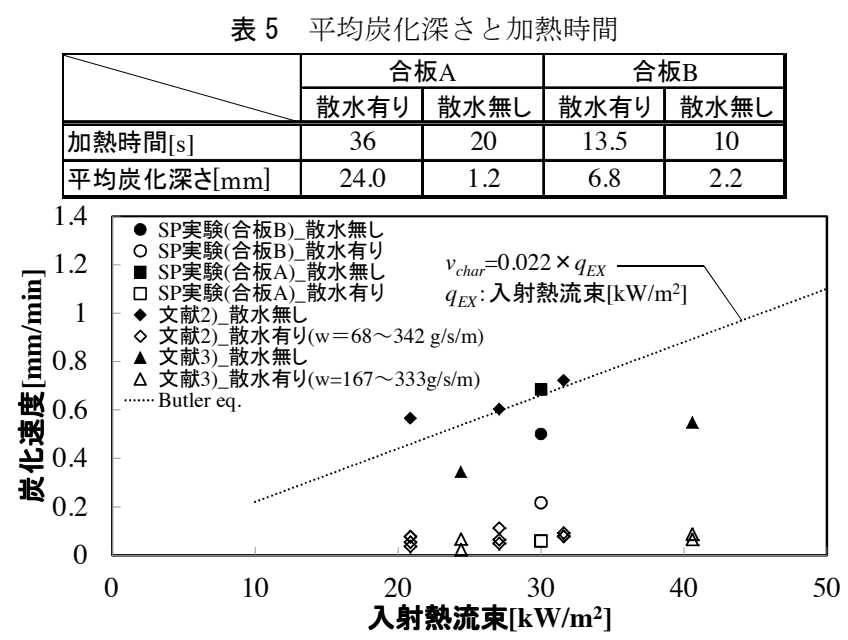

図 9 入射熱流束と炭化速度

\section{5. まとめ}

SP 作動時における木製内装材を用いた壁の発熱速度などの燃焼 性状に関する定量的知見の収集を目的とし、自由空間において木製 内装材を模擬した合板の壁の燃焼実験を実施した結果、本実験の範 囲で以下の知見を得た。

（1）試験体の単位幅当たりに供給される平均散水量は $49.2 \mathrm{~g} / \mathrm{s} / \mathrm{m}$ 、 試験体の散水範囲の単位面積当たりの平均散水量は $20.56 \mathrm{~g} / \mathrm{s} / \mathrm{m}^{2}$ 之 なった。また、火源から試験体一入射する熱流束は試験体中央下端 から高さ $\mathrm{H}=455 \mathrm{~mm}$ の位置で約 $30 \mathrm{~kW} / \mathrm{m}^{2}$ であった。

(2) 散水無しの場合、試験体の発熱速度は最大で、合板 A の場合 $450 \mathrm{~kW}$ 、合板 B の場合 $500 \mathrm{~kW}$ まで到達したが、散水を開始す
るとほぼ $0 \mathrm{~kW}$ となった。

（3）散水無しの場合、試験体下端から合板 $\mathrm{A} の$ 場合 $0.9 \mathrm{~m}$ まで然え 抜け、合板 $\mathrm{B}$ の場合 $1.2 \mathrm{~m}$ まで顕著な炭化が見られたが、散水有 りではこのような燃え抜けや顕著な炭化は見られなかった。

（4）散水無しの場合、いずれの高さにおいても裏面温度は時間と共 に上昇し続けるが、散水有りの場合、温度上昇は抑制または低減 され $40{ }^{\circ} \mathrm{C}$ 以下となった。

（5）散水無しの場合、試験体の対向面の放射熱は約 $1.2 \mathrm{~kW} / \mathrm{m}^{2}$ で推 移するが、散水有りの場合約 $0.1 \mathrm{~kW} / \mathrm{m}^{2}$ まで低下した。

\section{謝辞}

本報告は国土交通省平成 24 年度建築基準整備促進事業「防火・避難対策 等に関する実験的検討」における共同研究の成果の一部をまとめたものであ る。同事業の委員の方々には実験計画に際し、多くの助言をいただきました。 また、実験の実施には、緒方貴憲氏 (東京理科大学大学院大宮研究室)、牧野 淳氏、山田信太朗氏（当時、東京理科大学大学院大宮研究室）よりご協力い ただきました。ここに謝意を表します。

注

注 1) 本実験で想定した SPヘッドと壁 (試験体)の位置関係を図 10 に示寸。 図 10 のように、壁面の延長線上に SP ヘッドを中心とする半径 $2.6 \mathrm{~m}$ の円 と仮想の隣の $\mathrm{SP}$ ヘッドを中心とする半径 $2.6 \mathrm{~m}$ の交点になるよう壁 (試験 体）と SPヘッドの距離を調整した。

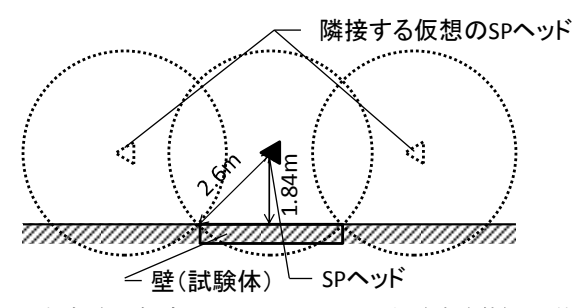

図 10 本実験で想定した SPヘッドと壁（試験体）の位置関係

注 2）ガスバーナーに点火してからガス供給量が安定するまでの時間は概ね 10 分程度であった。

注 3）合板 B で加熱開始後 $250 \mathrm{~s}$ 付近で $10 \mathrm{~kW} / \mathrm{m}^{2}$ 以下の発熱が生じている のは、可燃物表面が燻焼したためと考えられる。

注 4) 本実験では燃焼生成ガスがガス分析計内に到達する前にサンプリング ガスを常温まで冷却し結露水を除去しており、水の蒸発に伴う水蒸気が酸 素消費法の結果に与える影響が大きくならないよう配慮した。

注 5）ただし、この散水量は SP ヘッドから散水マスに直接入る水量や試験体 表面から跳永返った後散水マスに入る水量が含まれている。

\section{参考文献}

1）園田岳志, 小林武雅, 大宮喜文, 鈴木淳一 : 水膜を用いた火災加熱低減効 果 その 2 実験結果及び数值解析結果, 日本建築学会関東支部研究報告 集, pp.317〜 320, 2006.3

2）田中透一, 鈴木淳一, 大宮喜文: 水膜形成による火災外力の低減, 日本建 築学会関東支部研究報告集, pp.373 376, 2005.3

3) 東京大学岡島研究室: 流水膜の防火に及ぼす影響, 火災の研究 第 2 巻, pp.94 96, 1953.10

4）土橋常登, 田坂茂樹, 吉田正友, 田中哮義 : 加熱を受ける壁面への事前散 水による延焼防止効果に関する実験, 日本建築総合試験所研究報告 Vol.32 No.4, pp.35〜41, 2007.10

5) C.P.Butler : Notes on Charring Rates in Wood, Fire Research Note No.896, 1971.11

[2013 年 6 月 19 日原稿受理 2013 年 9 月 26 日採用決定］ 